\title{
The archives of terror and mourning in contemporary Spain
}

\author{
Alfonso Manuel Villalta Luna \\ Universidad Nacional de Educación a Distancia (UNED) \\ e-mail: a.villalta@fsof.uned.es
}

\begin{abstract}
Submitted: 24 September 2014. Accepted: 31 October 2014
ABSTRACT: This article takes an integral approach to the documentation generated during the Francoist dictatorship as a result of repression. It analyzes the different typologies of the archives of Spanish repression, ranging from the records and case files produced by repressive institutions to family archives containing personal documents that are witness of the repression. These private archives safeguard family memory by preserving objects and documents which include family letters, postcards, photographs, drawings and many other materials that belonged to disappeared ancestors. Finally, the article reflects on the benefits of a public memory policy which tackles the recovery, custodianship, preservation and dissemination of all these documents: a fundamental task in forging a collective memory of the people and forming a shared identity among its citizens.
\end{abstract}

KEYWORDS: Archives; repression; memory politics; memory and history; private documentos; Francoism; the defeated; patrimony

Citation / Cómo citar este artículo: Villalta Luna, Alfonso Manuel (2014). "The archives of terror and mourning in contemporary Spain”. Culture \& History Digital Journal, 3(2): e021. doi: http://dx.doi.org/10.3989/chdj.2014.021

RESUMEN: Los archivos del terror y del duelo en la España actual.- Este artículo aborda, de manera integral, la documentación generada durante la dictadura franquista como consecuencia de la represión. En este sentido analiza las diferentes tipologías de los archivos de la represión españoles: desde los archivos y los expedientes producidos por las propias instituciones represoras hasta los archivos familiares que guardan documentos personales testigos de esa represión. Estos archivos privados preservan la memoria familiar a través de la conservación de objetos y documentos como cartas familiares, tarjetas postales, fotografías, dibujos y otros tantos materiales pertenecientes a sus antepasados desaparecidos. Por último, reflexiona en torno a los beneficios de una política pública de memoria que se preocupe de la recuperación, custodia, preservación y difusión de todos estos documentos; labor fundamental para forjar la memoria colectiva de un pueblo y la identidad común de sus ciudadanos.

PALABRAS CLAVE: Archivos; represión; políticas de memoria; memoria e historia; documentos privados; franquismo; vencidos; patrimonio

Copyright: (C) 2014 CSIC This is an open-access article distributed under the terms of the Creative Commons AttributionNon Commercial (by-nc) Spain 3.0 License.

\section{INTRODUCTION}

The reasoning behind this article begins in every dark Francoist cell and at every cemetery wall of all those Spanish cities where the silence of the early hours was punctuated by the volleys of firing squads, followed by the repeated dry, sharp and brazen sound of each coup de grâce. It is the history of each of the official documents that led the victims of Francoist repression to this situation and that of the objects, letters and scraps of handwritten paper that victims tried to get to their families so that at least their memory would not be silenced and buried too. This paper seeks to probe into the recovery of the documents and objects that have left a trail of the tragedy of this repression. The trail can be followed in the archives generated by the repressive organizations them- 
selves, which kept a large part of the body of documents testifying to their actions, in what we might call the "Spanish archives of terror". It can be followed, too, in each of the private documents so carefully kept in the most secret places of their own homes by relatives of the victims of repression, in their bid to keep alive the memory of their now absent ancestors.

The article is divided into three parts: in the first, I shall try to establish a typology for the archives holding documentation pertaining to the different repressive processes, the contents of which share certain characteristics with repression archives in countries in the Southern Cone. I shall then go on to focus the analysis on the documentation comprising private records, where family memory is safeguarded through the conservation of objects and documents owned by ancestors who suffered reprisals. Finally, I shall reflect on the benefits of a public memory policy that tackles the recovery, custodianship, preservation and dissemination of all these records. It is a fundamental task in forging a collective memory of the people and forming a shared identity among its citizens.

The debates surrounding the gestation and administration of archives of repression in Latin America have provided a crucial model in helping to explain the current situation of these archives in Spain. Their example has forced us to realize the importance of considering different typologies of repression archives as a whole, and of the need for an integral archival policy to administer them.

Archives of this type have always played a prominent role to the extent that they administer a major documentary asset. From the moment they are generated, usually by government institutions, they have been considered fundamental to serving the ends of power. Subsequently, once opened up to researchers, these institutions have then shifted the focus more towards historical investigation. But there can be no doubt that one of the moments at which the archives acquired critical importance was during the processes of political transition away from dictatorial regimes. In these processes, the archives took on a particular salience, becoming essential for the smooth implementation of new democratic regimes.

During the political transition in Spain, archival policies did not give this kind of archive the importance it deserved; political attention was not focused on the issue and, indeed, even preferred to look the other way. This accounts for the anxiety and lack of answers experienced by hundreds of thousands of citizens who, under the auspices of the new democratic regime, sought information and documents on the victims of the repression to retrieve the memories of their departed relatives and find out the truth. Yet applications made to public institutions and archives largely remained unanswered. The lack of response was officially justified as a consequence of the disorganization of these archives, but in reality concealed a total lack of interest in archival management and, moreover, premeditated political inaction to prevent these issues from being investigated further. The consequences of such political inaction on the archives during this period continue to be seen today, to the extent that, in some cases, almost no progress has been made on the initial situation, with the occurrence of major malfunctions in the archives in the present day (Corominas Noguera, 2008: 293-294).

Despite these difficulties, relatives and researchers have not forgotten their claims and continue to fight against the social injustices committed during the war and post-war period, and against ignorance of the truth and lack of reparation to victims. The first step in responding to these claims is for political power and society to accept these records as the depositaries of the memory of the people and for this to be considered their major social function. P. Nora (1984: 34) attributes the symbolic category of lieux de mémoire or "sites of memory" to archives, indicating that even a place of purely material appearance, such as an archive, is a site of memory if the imagination endows it with a symbolic aura. It is in the archive where the dilemma involving memory and history that concerned Halbwachs (2004) is most clearly reflected. Indeed, this author points to the appropriateness of using the term memories rather than memory, in view of the existence of individual, collective and social memories: collective or group memory goes beyond individual memory, while social memory is that of society when considered globally. In Halbwachs's view, there is a recollection process that goes beyond each subject, which is impersonal and in which individuals participate, albeit partially and in line with their own private interests. Every individual memory is developed within the realm of social memory. He goes on to state that individual memory is no more than a part and aspect of group memory (Halbwachs, 2004: 7-11, 105 and 174). Consequently, any memory is always collective. In this sense, linked to this previous concept, we need to add the term identity, understood as a construction fuelled by historiography that is based on or derived from collectivity.

For its part, "general history starts only when tradition ends and the social memory is fading or breaking up". Collective memory "is a continuous current of thought", since it "conserves nothing from the past except the parts which still live or are capable of living in the consciousness of the groups keeping the memory alive", and "by definition, it does not exceed the boundaries of this group". History, on the other hand, is situated above specific groups (Halbwachs, 2004: 79-80). In short, for Halbwachs, memory is constructed from within the group; history, on the other hand, is constructed from outside. Memory is alive, retains what remains alive, and is capable of living within group consciousness; history, meanwhile, is dead because it only starts when tradition and social memory end.

On this dilemma, the contributions of Paul Ricoeur shed light on the definition of the archive when understood as a key element in constructing collective memory. The archive presents as a physical place which shelters the destiny of the documentary trace left by a society, "but the archive is not just a physical or spatial place, it is also a social one", as it belongs to society and guarantees the conservation of shared collective memory (Ricoeur, 2004: 167). 
In Spain, there is still a long way to go for archives to be considered and valued as sites of memory. One of the keys to achieving this lies in their identification as "territories of memory" (Da Silva Catela, 2002a: 15-84). This idea is linked to a concept of struggle in which these spaces are conquered as places of memory that hold not only history, but also social, cultural or political memory, of which they are the source, irrespective of whether or not they have been appropriated by an "official memory". The leading role in this struggle has been played by the relatives of Latin America's political disappeared where archives have become a key element in discovering the truth and getting justice for the victims of repression in different military dictatorships. Consequently, combined political and social actions are necessary to give archives decisive support in this leading role.

\section{THE ARCHIVES OF REPRESSION. TYPOLOGIES}

The archives of repression are mainly defined by the documentation they hold. The common standard is that they have been generated in circumstances related to human rights violations. In addition, most of the documents were produced by the institutions responsible for this repression. On many occasions, the documentation was created by actions that were arbitrary, to say the least, and where physical or psychological violence was used (Da Silva Catela, 2002a: 21). They also include the documentation produced by all the institutions and bodies that opposed the repression, held in the archives of the major underground political parties, including, in the Spanish example, the PCE (Communist Party of Spain) and the PSOE (Spanish Socialist Workers' Party).

A characteristic common to all this documentation is that it was produced at moments that Pollak (2006) defines as "limit situations". These situations comprise the reactions of individuals and groups to extreme situations that entail unprecedented actions when faced with the unpredictable. He adds that any limit experience is revealing of conditions that in "normal" situations, remain concealed.

In an attempt to establish a typology ${ }^{1}$ of archives of repression, the main distinguishing element is an archive's origin or provenance. In this way, two main categories can be established, based on whether the documents are public or belong to institutions or political parties who have opened their doors to researchers; or whether they are private, by which I mean family and personal archives, and are therefore of a more intimate nature.

1. Archives of the repressive bodies and institutions or archives of terror: they have been given this name for the kind of documentation they hold. They include sets of archives compiled by state security services, the records of different kinds of courts, especially military tribunals, the archives of penal institutions, of the forces of public order and judicial files in the broadest sense. The most important aspect of these archives is what González Quintana has dubbed the "boomerang effect" (2009: 35). By using this term, the author is referring to the paradox that the main institutions responsible for the repression during the dictatorship years are, today, the very institutions which hold all documentary evidence of it $^{2}$.

In this respect, the most characteristic element is the repetition of this "boomerang effect" which can also be extended to the current role of the documents. Whereas, in origin, their main purpose was as inculpatory evidence against the accused, they can now be used to compensate victims through public recognition of the unfairness of their trials. Like other historical archives, they represent an inexhaustible source for extensive historical, sociological and anthropological analysis, enabling the reconstruction of our most recent history. However, these documents - initially created to give legal capacity to acts of repression - can now be used to reconstruct the fragmented stories of their victims and to probe into the logic of the repressive action in question. They often become the "receipt" that the relatives of victims turn to in order to help fill in the details regarding the harshest episodes in the lives of their ancestors and to find answers to gaps in family memory as a way of carving out their identity.

It should be noted that part of the documentation generated by the repressive institutions has now been handed over to national archives. The most important of these include the Centro Documental de la Memoria Histórica [Historical Memory Documentary Centre], the Archivo General de la Administración [General Administration Archive] and the Archivo Histórico Nacional [National Historical Archive]. However, as I have said, the vast majority of documentation remains in the hands of the very institutions that created it. These archives of terror include general military archives belonging to the Ministry of Defense, justice administration archives and the archives of the Ministry of the Interior.

Without seeking to be exhaustive, since I do not aim to conduct a systematic study of all the different archives in existence and the assets held in each collection, I shall refer to some of the most interesting records, by way of example. Let me focus first on what can be defined as the archives of terror and within this group, begin by mentioning one of the most important sources: the records held in military archives. This very important documentation has only recently come to light, owing to restrictions of access. That it is of great interest is beyond doubt, as these archives contain of the documentation generated by the courts martial and the summary trials conducted by military tribunals ${ }^{3}$. From them, we can obtain very valuable information both on the victims and their executioners. These sources provide us with a more accurate picture of the nature of Francoism, the cases brought and the typologies of the offences and penalties imposed on men and women. Moreover, as I have indicated, they serve to identify and reveal more about the investigating judges. Every case includes a series of useful documents, such as the information generated by the Civil Guard, indictments, accusations, auditors' reports and rulings.

In this same category, we must include the archive of the Civil Guard and the police, both of which belong to the Ministry of the Interior. These archives have a mor- 
phology of their own and documentation can be divided into the personal records of purged members of the different forces and documents generated as a consequence of one of their main functions, namely social control. In this respect, the police archives are full of files and personal records, reports on socio-political conduct and political responsibilities and police identification photographs. The Civil Guard files also contain important documentary information on the repression of anti-Francoist guerrillas. As above, they also hold the dossiers of purged Civil Guards. ${ }^{4}$

Francoist jails were to become one of the major centers of repression during the dictatorship. Prison archives hold the documentation from this period and represent a vital consultation source for finding out more about the lives and deaths of prisoners. This documentation covers a wide range of aspects on life in jail, including discipline, health, food and daily coexistence, as well as specific details on each prisoner, such as the date of their imprisonment and a section for comments which provides very interesting information regarding prisoners' circumstances and sentences.

I will also refer to those national archives to which documentation on repressive processes has been transferred. These do not fall under the category of archives of terror as it is not the same institution that generated the documentation that now holds it. The main archive with information relevant to the study of the repression is the Centro Documental de la Memoria Histórica [Historical Memory Documentary Centre], based in Salamanca and created from the Civil War Section of the Archivo Histórico Nacional, with a view to storing all the documentation seized by the dictatorship during the war by what was known as the Delegación Nacional de Servicios Documentales or National Delegation for Documentary Services, which was designed for repressive use in the postwar period. This archive also contains, among other sources, a section covering the records of the Special Tribunal for the Repression of Freemasonry and Communism, which had special jurisdiction to repress people deemed to fall into either of these categories.

The Archivo General de la Administración (AGA) is also significant in this respect, and contains documents with valuable information about repressive processes and the subsequent control of citizens who were not pro-regime, as well as substantial records pertaining to the purge in education. Finally, the Archivo Histórico Nacional $(\mathrm{AHN})^{5}$ holds one of the sources most often used in historiography. This is the Causa General - currently accessible digitally on the Ministry of Culture's PARES website which entailed the compilation, village by village, involving both different local institutions and the neighbors, of information on the actions of any individual in the civil war, giving rise to a genuine inquisitorial process throughout Spain.

2. Archives of "clandestinity": these archives have been compiled in parallel and in open opposition to the archives of the repressive bodies. They include the records of the different political parties, unions and associa- tions opposed to Francoism that operated in the country illegally, as well as those of all the anti-regime institutions created in exile. These documents had to survive the vicissitudes of the underground struggle and only a part of them have reached us today, but they have become crucial to complete our knowledge of the past and as alternative sources to contrast with the official history of dictatorial regimes.

These documents followed the same path as the institutions that created them since, with the advance of Francoist troops, republican political and union organizations withdrew to areas as yet unoccupied and, subsequently, once the war outcome was decided, went abroad. In the final months of the war, events caught up with them, and the documentation also suffered the consequences: it was partly abandoned, partly destroyed to prevent its use for repressive ends and to a large extent taken outside Spain. Any documentation that could be saved then remained abroad for many years until, with the arrival of democracy, some of it could return to become part of the collection of documents created by these exiled institutions.

This process of documentary retrieval has been carried out by different political parties through their respective foundations. ${ }^{6}$ Reference must be made here to some of these foundations, but making a distinction between the documentation produced in exile and that created both during the war and afterwards in the clandestine period, though still in Spain. I shall outline briefly the documentation held at some of these foundations, and in particular the documentation of the most prominent political parties in this period.

Firstly, I shall focus on the repositories of the Republican Left, held at Fundación Luis Bello. The documents found here, mainly donated by militants, are essential to retrieving the past of republican organizations. Their assets include documents on the period of exile in Mexico, with sections like the one devoted to the Centro Republicano Español de México and to Acción Republicana Democrática Española (ARDE).

Fundación Pablo Iglesias ${ }^{7}$ has accumulated documentation belonging to the main Socialist organization, the Spanish Socialist Workers' Party (PSOE), and also on the Socialist Youth and UGT unions. Among the specific assets devoted to exile, we find that of the PSOE Executive Committee in Exile with the information generated by this governing body, as well as the repository of the Federación Nacional de Juventudes Socialistas de España en el exilio [National Federation of Spanish Social Youth in Exile].

The most paradigmatic example of an archive in clandestinity in Spain is the Archivo Histórico del Partido Comunista de España [Historical Archive of the Communist Party in Spain]. ${ }^{8}$ Like the previous documents, it contains very valuable information, contributed by its militants, providing records of a number of aspects, such as arrests, interrogations and detentions at police stations. Moreover, a large part of the holdings include documentation belonging to the Communist Party of Spain (PCE) taken abroad during the war, microfilmed and held at different countries of destination. It also holds records on 
party militants in exile, known as the archive of the PCE's International Relations showing the party's contacts with other Communist parties in other countries. ${ }^{9}$

Finally, mention should also be made of the documentation drawn up in the different countries of destination of Spanish exiles. This has been gathered together in archives with a view to holding these in host countries. Part of this documentation is now being brought back to Spain by Spanish archives using different acquisition methods. The Centro Documental de la Memoria Histórica [Historical Memory Documentary Centre] is the main archive to have received these records. ${ }^{10}$

3. Private archives or archives of mourning: in the private sphere, the documents on the repression have become the records that fracture family history and memory. The remainder of these documents sometimes evokes a moment when everything changed and after which nothing would ever be the same; in other cases, it recalls happy times prior to the repression. It is access to these happier times that help us understand how the world changed for those who suffered reprisals and their families. The word archive may be associated with a box hidden in a drawer, a letter that was kept, pictures set aside from normal everyday family life or any other object that bears witness to and recalls the life of a person no longer there. What all of these objects have in common is that they have been kept for decades and, usually, somebody in the family has taken charge of them, thus becoming the "guardian of family memory" (Da Silva Catela, 2002b: 199). They are archives of pain and mourning, a mourning which, given the frequent impossibility of discovering where the loved one has been buried, is the only way of confronting their absence. But they are also archives of resistance and hope, archives that give memory a safe haven, since direct contact with the objects of relatives who have disappeared, confers mental strength on those still alive.

Remains of this kind of private documentation can also be found in the archives of terror referred to above. This is documentation that was taken out of the family realm, using different mechanisms associated with postwar investigation into the political and social conduct of anyone suspected of not supporting the principles of the new regime. These investigation processes were usually initiated as the result of an allegation made by somebody in the victim's close circle, leading to a search for any documents that could be considered evidence against them. Thus, ordinary documents like letters, photos or a simple piece of paper written before the war, could be used as evidence in the entirely summary trials that took place afterwards. These records also include membership cards of political parties or unions and a vast array of documentary typologies that have reached these public archives as a result of judicial proceedings. The opening up of the archives of terror, and the access of relatives to these private materials removed from the family environment and taken away for decades, permits the release of what we might refer to as the captive memories of victims which have remained hidden in the dark archives of any of these institutions. Once these objects and documents have been accessed, the family memory, on which such restrictions had previously been placed, can then be completed.

4. Finally, an outline must also be included of archives currently under construction, which we might refer to as the archives of civil society. ${ }^{11}$ These archives contain data and research compiled both by different civil associations, immersed in the memorialistic process, and by different research projects of an academic nature with regard to any repressive practices and other less tangible actions of repression. In most cases, they are archives in the process of development which have been taking shape over the last decade, in which pro-memory policies, research into the repression and the exhumation of mass graves have produced huge amounts of information that now need to be managed. All of these archives are engaged in this process of managing the information gathered, but each is at a particular development stage and entirely different in nature, both because of the kind of information being handled, the formats and an infinite number of other specific aspects. The information compiled may be either public or, in the cases where it is provided by relatives, private.

The proper management of all this information is of the utmost importance because, as has been demonstrated in different transitional justice processes in other countries, especially in the Southern Cone, this documentation has become a unique source for knowledge of the past. Above all, however, it is evidence with which to settle responsibility for human rights violations and is a crucial element in victims' demands for reparation. These archives are therefore a key aspect in the process of obtaining justice for these crimes.

\section{THE PERSPECTIVE OF THE DEFEATED: PRIVATE DOCUMENTS TO RECONSTRUCT FAMILY, COMMUNITY AND SOCIAL MEMORY}

The memory of Francoist victims is caught up in the archives of terror like an insect trapped in amber. Individual memory is trapped in time and encapsulated in archival repositories to which neither researchers nor relatives have had access until very recently. Access to official documents was denied by the institutions managing these archives, which have failed to respond to requests for access by relatives anxious to complete the distorted family memory. Even today, researchers and historians are given only partial access, on grounds of data protection acts that do not actually conflict with the researcher's quest, which is hampered by a whole array of obstacles. Thus, like family memory, the social memory of the most traumatic episodes in Spanish history-resulting from war and post-war-remains at a standstill, trapped in time.

As a counterpoint to this trapped memory, private documents that constitute the only memory possible have, out of fear for its very existence, been carefully guarded for many years in the most secret places in the homes of 
Francoist victims. These new sources allow the picture to be completed and light to be shed on what official sources have hidden. They help construct a "fairer and more democratic history, closer to the truth and more human" (Sierra Blas, 2009: 3).

The most significant beginning to the re-evaluation of personal documentation in the historiographical tradition was that of the later subscribers to French historiography's Annales School. In Spain, we have to go back to the 1990s when, during the boom in social history, historiography started to focus on new historical subjects, paying attention to that part of the population that had been sidelined from the elite circles of political history. From that moment on, socio-cultural history paid increasing attention to the working classes and interest grew in the study of their living conditions and daily-life experiences (Casanova, 2003: 20). As a result of this new interest, those who so far had considered themselves the true protagonists of history, namely political parties and their leaders - had to make way for the introduction of working class history. As a result, during recent years, considerable attention has been paid to the defeated side in the Spanish Civil War, excluded from history for many years (Casanova, 2009: 155163). Yet that spotlight on the defeated has continued to focus primarily on those who were able to go into exile after the war. These have had their own voice in historiography and their accounts have served to document part of the history of the repression. What has been left in the dark, however, is the account of the defeated who were neither leaders nor exiled, whereas the voice of the victors has continued to be heard inside the country.

There therefore remains much to be done and many research objects to analyze. The study of these new sources, which are useful in describing Francoist repression and its non-accounting entries, ${ }^{12}$ requires us to broaden the methodological approach and maintain an eclectic perspective as to the theoretical channels of analysis. In this respect, it is important to position ourselves at the convergence between social history and the history of attitudes. We need to recover the history of attitudes, a hugely appealing history which draws attention to practically untouched research material, offering the possibility and posing the challenge of scrutinizing the way that, as historical subjects, the victims of Francoist repression thought, felt, imagined and behaved, and an interdisciplinary endeavor is required to achieve this.

This endeavor would lead to interesting new lines of research, since personal documents are an inexhaustible source of study material. All that is needed is for an interest to be taken, and, as Plummer puts it:

The world is crammed full of personal documents. People keep diaries, send letters, take photos, write memos, tell biographies, scrawl graffiti, publish their memoirs, write letters to the papers, leave suicide notes, inscribe memorials on tombstones, shoot films, paint pictures, make music and try and record their personal dreams (...) All these expressions of personal life are hurled out into the world by the millions and can be of interest to anyone who cares to seek them out (Plummer, 1983: 13).
In this research framework, we need to introduce the differential consideration of subjectivity and objectivity in its analysis. When exploring the historical object, subjectivity should not be condemned a priori, rather the contrary. The engagement of the historian, both cognitively and emotionally, should be considered a positive element as an experience that generates historical knowledge and a legitimate way of attaining it.

We need a broad theoretical framework that attaches importance both to the differential consideration of subjectivity and the introduction of emotion into historical analysis with the use of private documents as a valid source to create historical knowledge. This is the only way to understand history in its entirety, making space for that other dimension, the version of those who had, until now, been silenced.

Despite the methodological progress indicated, it remains difficult to overcome the barrier, especially in the area of historiography, and to give intimate or private sources the same validity as the more traditional archival sources.

The main reason why this barrier has remained in place is the consideration that official sources are closer to what might be considered to be an "objective truth". The acceptance of official documents as an objective truth is, in fact, increasingly removed from the position of academic circles. Even so, a certain inertia remains in this respect. The argument in favor of the truth of official documents is, of course, very weak, since every document has been created for a specific purpose. Where archives of repression are concerned, which are official archives, a clear example of this lack of objectivity are the highly summary trials conducted by court martials during the post-war period, and the documentation associated with them, all of which must be approached with the greatest caution.

All these processes involved practices that were frequent at that time, such as allegations, denunciations and false testimonies. In this respect, both the document that usually initiated any proceeding, namely an allegation, and all the documents generated in the course of that proceeding should be analyzed within clearly defined limits. Even the witness statements of defendants is open to question, given that what they said at that time would determine whether or not they were condemned to death. Finally, court rulings are one of the elements that arouse most suspicion in terms of validity as these "prove" a series of facts that are usually improbable. In short, all these documents are the product of the "limit situations" defined by Pollak.

To probe further into these considerations, I will use a concrete example from a summary trial. In this case, the proceedings were brought against Amanda Jerez Martínez, ${ }^{13}$ a republican schoolmistress in Almadén, Ciudad Real. At the age of 27, after teaching in this town for seven years, she had become the headmistress at the school attended by mine-workers' children. The case was brought against her on May $7^{\text {th }}, 1939$. In her witness statement (Fig. 1), we can read that Amanda denied a series of horrifying accusations, including: 


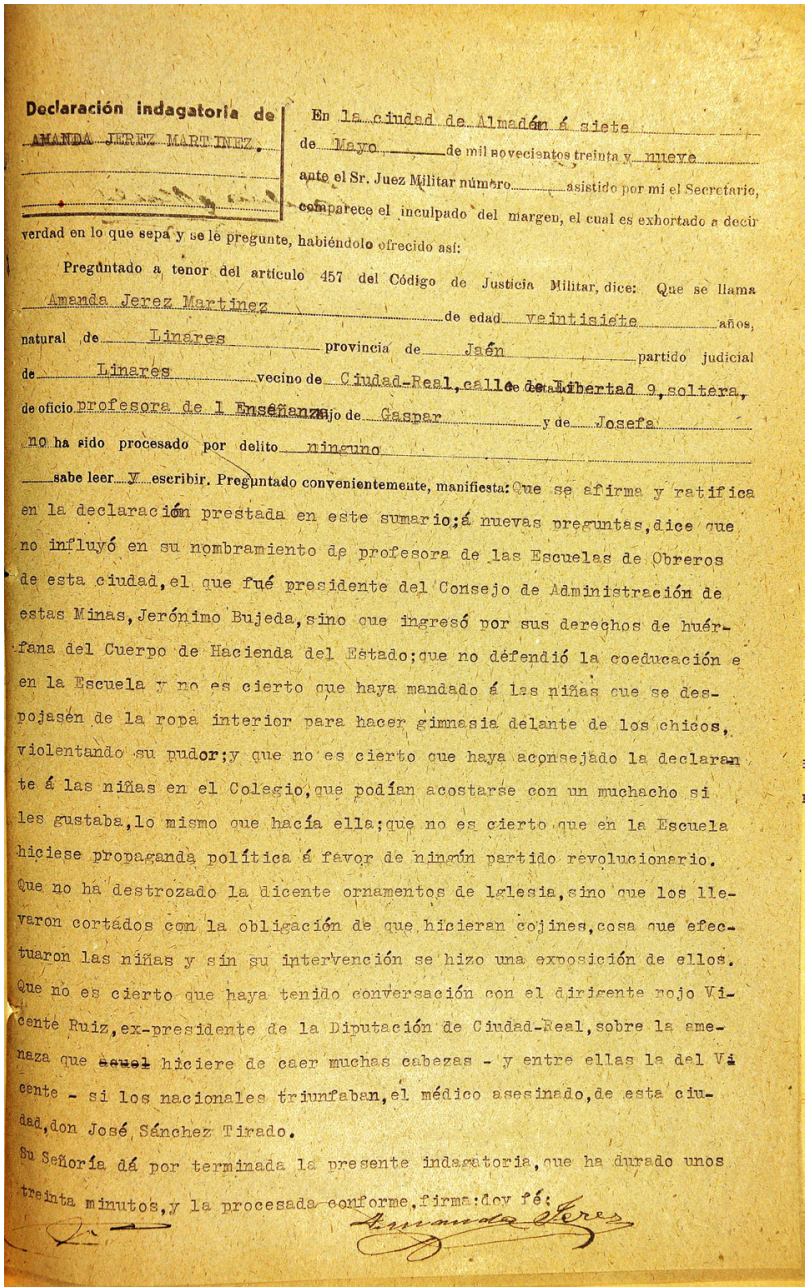

Figure 1: Witness statement of Amanda Jerez. AHD, JM, Leg. 2934, Sum. 2323

...That she did not defend coeducation in the school and it was not true that she had sent the girls to take off their underwear to do gym in front of the boys, thus assaulting their decency; and it was not true that she had advised the girls in the school that they could go to bed with a boy if they liked him, the same as she did.

In addition to this, she was accused of having been involved in the expulsion from the school previously cited of the headmaster and three other teachers for being right-wing. One of the witnesses at the trial, a colleague of Amanda, even accused her of "an intimate relationship with the [left-wing] leaders" of the town. As a result of this relationship, she was said to have connived in arrests that took place. The same witness accused her of teaching "purely Marxist and immoral doctrines" at the school and of "preaching free love", taking the accusation made above even further.

The only documentary evidence used at the trial to prove her guilt, other than witness testimonies, was a piece of paper containing some handwritten verses (Fig. 2; Fig. 3). One of the witnesses links them to Amanda in a statement saying that "she made up and consented to the making up of verses offensive to the teachers". This is the transcribed evidence that is said to reflect this offence:

\begin{abstract}
Alma De Payaso Lo que pasa en la escuela de Hijos de Obreros
I Detrás de su persiana/estaba la del ciego/de rabia enfurecida/escuchando el cantar/que el borrado clama/pidiendo la justicia/que quiere que se haga/con ese Director/ Mas todas las beatas/que son de su cabaña/defienden al tirano/y hasta lloran por él/y el pueblo ve muy injusto/ [doblado]/y que se marchen todos/juntos al mismo tren/ Reírse muchachos/ y seguir con vuestra empresa/y pedirle a don César/mi nuevo Director/ Pedirle muchachos/ que no venda becas/ni venda vuestros libros/a los de su elección.

II La que más lo defiende/en esto es la Esperanza/como es su antigua/siempre recordará/aquellos buenos ratos/ que (...) el [doblado]/y asustaba a las niñas/ porque iban a formar/y las demás maestras/contando a su compadre/ cómo piensan lo mismo/se van a su favor/en esto hay un misterio/que sienten de perderle/son los favorecidos/de su buen Director/ Reírse muchachos/y seguir en vuestra empresa/y pedirle a don César/Pedirle muchachos/... que no venda becas/ni venda vuestros libros/a los de su elección.
\end{abstract}

No regard at all was paid to the arguments in her defense and the court's ruling declared all the evidence to be proven. Thus, the military tribunal sentenced Amanda to life imprisonment as the perpetrator of a crime of Adherence to rebellion.

Standing in opposition to these official sources, we find a vast array of sources from the private realm. Historiography has already paid some attention to these sources to complete historical knowledge by introducing the histories of the lives of some of the losers of the war. To achieve this, attention has been focused on the biographies, autobiographies or personal archives of political leaders who played a prominent role in the war and who have narrated their experiences, usually from exile. This was the main way in which the perspective of the losing side of the war has been discovered. Yet this perspective has been limited to what political elites have written. A large part of these records have been preserved through the efforts of the underground archives that I have referred to above.

The biggest shortcoming has always been the perspective of the working classes, ${ }^{14}$ the people without History, the perspective of the defeated who have not played this decisive political role. As indicated above, we are acquainted with the perspective of a part of the defeated: those who were able to go into exile. But I am interested in discovering the perspective of that other part of the defeated, who continued to live in the same environment as the victorious, and who is also from the lower classes. This is the perspective of the defeated, who were left at the mercy of the victors, in a constant state of alert and danger, kept under surveillance and monitored even by those in their immediate circles.

This has been an ongoing deficiency, both in the historical field and in the process of developing social mem- 

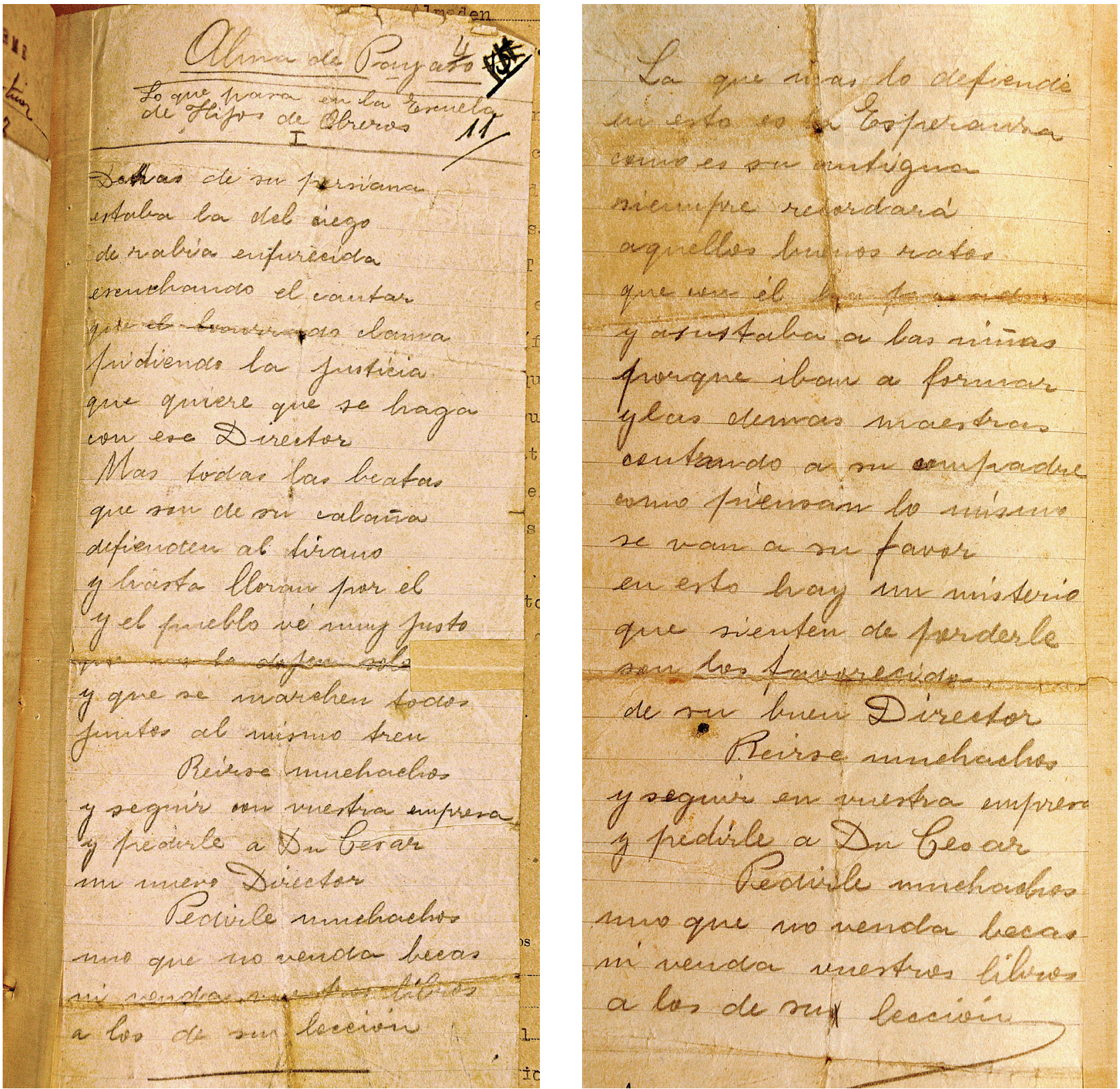

FIgURES 2 and 3: Evidence against Amanda Jerez. AHD, JM, Leg. 2934, Sum. $2323^{21}$

ory. The key question is how we discover the perspective of the defeated. The immediate answer can be found in the sources that they themselves created. In this case, these sources are the documents that were kept by their families. In the search for sources produced by the defeated, the most important precedent was set by Miguel León-Portilla (1984) who, in 1959, pioneered the debate on the perspective of "the other", in his case from the indigenous perspective before the arrival of the conquistadors. This represented a new historiographical approach in view of its main objective: to give a face to those who did not have one. Even in his introduction to the work, Portilla voices his concern for "the other face of the his- torical mirror", by which he is referring to the side laden with "profoundly human" testimonies in accounts that possess the spirit of defeat.

The fruit of another defeat - namely bitter defeat in the civil war - is the documentation created and objects left behind by the losers, each reflecting a family tragedy. But they are also the most traumatic memory of a whole nation. Accessing this realm, the most private family realm, is the key to knowing what these people thought and felt.

In contrast to the public sphere, in the private realm and in the silence of the home, the defeated resisted the official history that the regime sought to hoist upon them. 
Despite the difficulties, personal objects and the writings of those who experienced the war and subsequent repression did not disappear from the domestic realm. The memory and ideology of those whose relatives suffered from the regime's reprisals were preserved in materials that served as remembrance.

Julián López has defined the survival of these memories in the domestic environment as "those little things from a time of thorns" (López García, 2014). These objects, handed down from generation to generation, linked all the members of the family with their disappeared ancestors; in the case of those who did not experience those times, they are used to construct an inherited family history: photographs, a final letter, a document... with which they form "secular altars" (López García, 2011: 580), which become a safe haven at which to preserve a memory that they have been denied. These altars have another aim: faced with the terror imposed by dictatorial violence, which prevented even a space of mourning for victims' relatives, a covert mourning is constructed in the family environment to keep their memory alive. It is a mourning that is still concealed today, as it has often been impossible to bring this unfinished process to a conclusion. ${ }^{15}$ In most cases, families were not allowed to bury the bodies of their dead relatives, but nor could they bury their memory, owing to the emotive power given off by these objects and to the use relatives made of them, turning them into objects for memory and resistance. In short, the objects have become "memory condensers" (López García, 2014).

The exploration process to gain access to these hidden family treasures necessarily begins by resorting to oral sources, an interesting source in itself, especially when establishing a dialogue with the personal documents and objects kept by each family. But most interesting of all is to discover all the material that emerges as a result of an interview and which completes the accounts narrated. Exploring the private context requires special handling as it involves an "intrusion" into the very heart of the family, and therefore requires both time and special exploration conditions. Once this barrier has been overcome, we encounter further difficulty when it comes to locating the personal objects in question. All of these kinds of object had to survive extremely harsh conditions throughout the dictatorship, and their possession could sometimes be considered an offence and consequently extremely dangerous.

Evidence of how dangerous it was - when outlawed during the Francoist dictatorship - is a testimony gleaned from one of these "intrusions" into the family realm, in the shape of a Communist Party membership card (Fig. 4; Fig. 5), kept by the daughter of Isaac Mayoral Garrido "in a tin under one of the roof tiles"16 throughout the dictatorship period. In this case, both the object and the individual shared the same fate. Isaac Mayoral was hidden by one of his brothers when the war ended and spent time hidden under his brother's house, in a little niche dug out below the tiles of one of the rooms. Luckily he was able to escape and, however improbable, successfully eluded Francoist persecution. The card remained hidden without al-
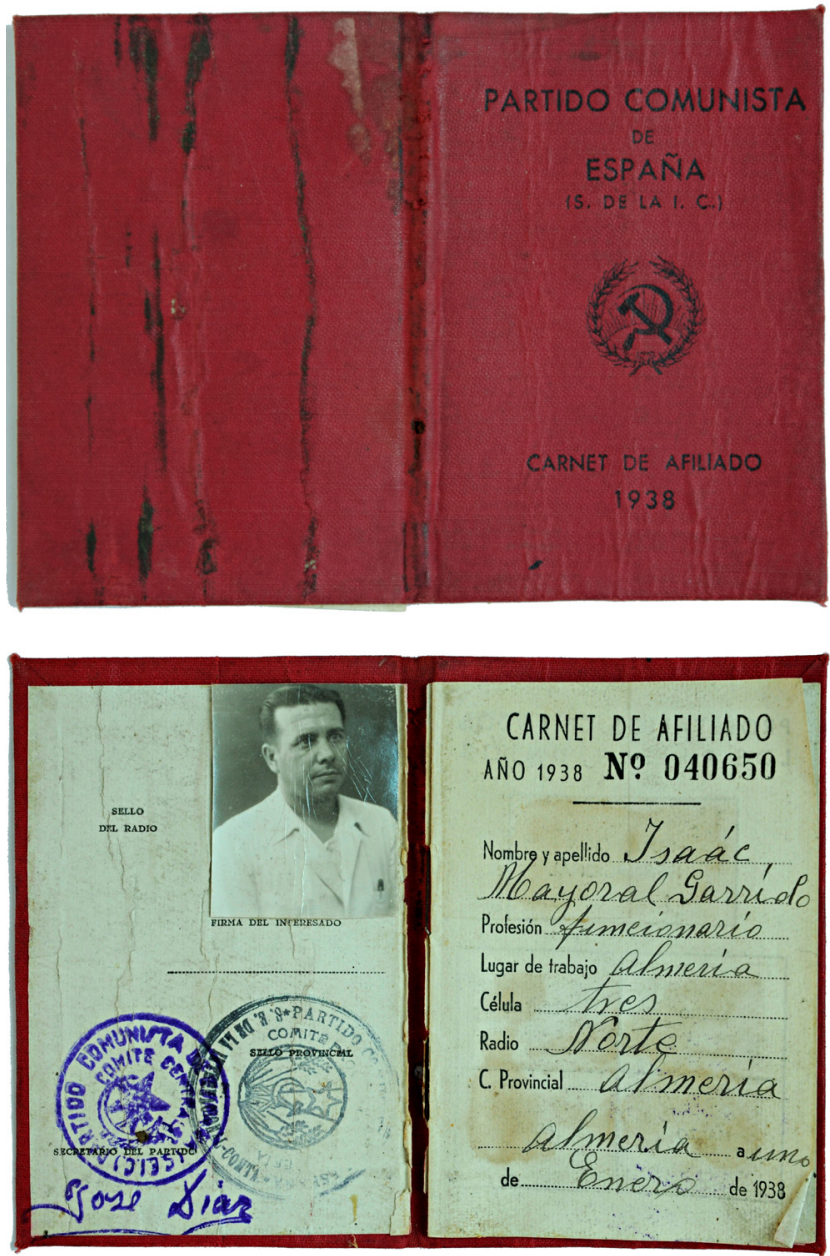

Figures 4 and 5: Isaac Mayoral Garrido's Communist Party membership card. Provided by Enriqueta Mayoral Barea.

most anybody knowing of its existence and where nobody had access to it. The object was hidden because Isaac was still being pursued: hidden to protect both his and his relatives' lives.

These personal documents, neglected for so long, must be urgently recovered, as there is an ever-dwindling number of people alive who are able to share their experiences and give these objects back their significance. This would also enable us to retrieve their exclusivity as a source and thereby depict the role of the defeated as extensively as possible. To explore in this way means to discover objectively the everyday life of those who suffered repression. The discovery of these records also enables us to bring to light personal tragedies, individual fears and the most solid convictions or ideas, and even though "on their own, these records do not make history, nor can history do without them, unless we wish to perpetuate some of the silences and oversights that have existed in the course of time" (Castillo Gómez and Montero García, 2003: 13).

Inside each of these family treasures, among the multiple objects and documents preserved, there are two found most frequently, which carry on an internal dia- 
logue in apparent response to the rhetorical questions of family memory: prison correspondence and photographs. The words of Didi-Huberman aptly describe this dialogue between the image and the written word:

For in each testimonial production, in each act of memory, language and image are absolutely bound to one another, never ceasing to exchange their reciprocal lacunae. An image often appears where a word seems to fail; a word often appears where the imagination seems to fail (Didi-Huberman, 2008: 26).

Letters from jail have become one of the most relevant and interesting sources to access the genuine reality experienced by both inmates and their relatives. They enable us to access the moment of greatest proximity of prisoners with their families and are essential for an overall understanding of the phenomenon of repression and the effects it caused by destroying victims' morale.

This correspondence involves two main kinds of letter: those that the prisoners and their families knew would be monitored and censored, and others which were able to evade controls in different ways. The best example of the latter are the farewell letters written the night before prisoners were shot, in which they reflect their true thoughts, worries, feelings and fears. The first kind of letter, on the other hand, has a different morphology, using language adjusted to necessary levels of correctness to avoid being vetoed by the censors. In some cases, prisoners were able to introduce subliminal messages, although these do not usually express the prisoner's true thoughts, feelings of fear, or if they do, they are sentiments that are usually communicated through code words and metalanguage.

Photographs are also of great value, as they recall the past, crystallize memories, help retain a clear picture of relatives' faces and evoke the history of each individual, creating a dialogue between image and word. In this way, the domestic photographs that would otherwise have occupied a prominent place in the home are kept in boxes and in secret places from which they can be taken out, only to be put back again. A multitude of torn photos, often sewn back to together, belong to this typology, revealing their fragility, and the wear and tear caused by being continually hidden away. They are a clear example of determination against the enforced forgetting, and their cracks evoke the fight to preserve the last memory of an absent person.

All these photographs show images of a past reality, recalling a series of affective resonances linked to a world that no longer exists. Their main value lies precisely in the historical moment to which they refer and the histories, images and emotions they are capable of evoking about that past moment. In short, the photograph has the capacity to make echoes from another time resonate in the present.

Having described personal objects as sources, a series of theoretical observations must be made with regard to the analysis method used. As I have indicated before, the marginalization of these sources in historiographical construction has been defined, above all, by accusations of subjectivity. These kinds of accusations seems totally ingenuous when we bear in mind that the other documents, considered official, are just as subjective and, above all, extremely partisan.

However, I would now like to take this reflection further and even defend the case for subjectivity and feelings in the analysis of historical sources. Ideas and feelings also construct History and it would be mistaken to think that the personality of individuals and their actions can only be explained through the rational dimension (Sierra Blas, 2009: 3).

In historical analysis, such sources are particularly appropriate to show the relevance of subjectivity - revealed through the affective and emotional relationship generated by these objects - because history is also made up of feelings and feelings are the common thread linking together all these objects. My aim here is to present the use of emotion as a new category of thought and awareness, seeking, by so doing, to focus on the significance of emotional motivations in the formation of images of the past. When considering the importance of bringing these objects into the public eye, Julián López asks: "How farreaching are the echoes of the whispers - or screams - of the little things?" (2014). The relevance of this process lies not only in the public recognition of victims through emotional rapprochement, but in following this up with political recognition. Consequently, the process of recovering these records must serve to:

Verify whether public awareness of these little mundane and private things can - if not echo with the culprits - at least affect others whose ideological, and I would say moral, neutrality has done so much harm in the processes of recognition and reconciliation (López García, 2014).

The device of empathy towards the victim of repression, whose most private declarations, feelings, thoughts and fears lie so transparently before us, is essential to understanding any social phenomenon in all its complexity. In dialogue with historical science, empathy can create a much closer, more human knowledge of reality, as well as having extraordinary didactic capacity. These objects have so far only had meaning in the family sphere, but from the moment at which they are known to another person, who can feel the emotion emanating from them, this meaning expands in the same way that a life, which had previously only been meaningful to the family, becomes another link in the recovery of a collective memory (López García, 2014).

\section{ARCHIVES OF REPRESSION AND PRIVATE DOCUMENTS: DEMOCRATIC HERITAGE OF A COUNTRY}

From the legislative perspective, the records held in archives are part of the documentary and bibliographical heritage of a country, even when this is not always made manifest in social consideration. In this respect, the documents that constitute the archives of repression require an 
even greater evolution if they are to be seen socially as sites of memory and for each of their documents to become "monuments of memory". This is the first step towards their forming part of the heritage of a nation and of its collective memory. It is a living heritage, laden with meaning in the current day and a cornerstone in the construction of a people's identity. The social and cultural role of archives is to preserve the necessary foundations for a society to be able to acknowledge its past. The social reconstruction of both social and collective memory must necessarily resort to this documentary evidence. It is here where archives play a decisive role, as the unflinching witnesses of the most important events experienced by a people (Lacerda, 2010: 127).

When considering archives and their holdings as cultural heritage, the inclusion of the most recent records of a difficult past like the dictatorial regime in Spain is an essential contribution to the consolidation of democracy. In this respect, the documentation drawn up during dictatorial regimes must also go through a democratizing process that guarantees social demands for plurality in collective memories. To achieve this, a public political debate on archival policy with regard to an authoritarian past, is crucial for any democratic society. This issue is closely related to the drafting of legislation clearly establishing how preservation and access to documents should be organized (Cruz, 2002: 170-171).

In Spain, we are a long way from this ideal situation. This distance does not appear to be a sign that society is incapable of looking towards a painful, complex, fragmented past, but instead reflects political disinterest in initiating a debate about public memory policies: a debate that is needed to confront and reach consensus on a common model for the conservation, custodianship and dissemination of this heritage. Its consideration as documentary heritage falls short in the absence of support for a public memory policy which makes focus on this kind of source its objective. The legislative context is a clear reflection of this political disinterest. ${ }^{17}$

I would like to take this idea further and include in this categorization of national heritage, all the documentation kept in private, family records: the private documents that have fashioned the history of the defeated side after the war, have witnessed individual histories and must now be transformed into collective memory when they are made public. Their inclusion is vital to complete the history of a country and improve the quality of its democracy.

All these documents, kept for their sentimental value in the homes of the defeated, have to be recognized as national heritage when they come to public attention. This is also a task for institutions and academic circles so that it can be generally acknowledged, once and for all, that there is also truth in all these documents and that they are all part of a new documentary legacy that must be gathered together and saved for the future. The next, essential step in this task is the indispensable dissemination of this material, to help us understand that a democratic society can only exist if everyone who is part of it is equally valued and has the same right to be heard, respected and recognized (Sierra Blas, 2009: 17). If this does not occur and the current pattern continues, whereby the personal memory of a large part of society is confined exclusively to the private, intimate sphere, then the problems derived from the difficulty creating a public space of dialogue and the resignification of memories will remain.

In this patrimonial conception of documentation about repression, we must make a distinction, for practical purposes, between the records held in the archives of repression, in which there has been a longer tradition, and private documents. The real challenge is the patrimonialization of the private records of pain. At the Department of Social and Cultural Anthropology at the la UNED, ${ }^{18}$ we are working on a protocol to manage and unlock the value of these private archives which would involve making these sources public through digital media so they are given the importance they deserve.

Regarding the documents held in what have been called archives of terror, González Quintana advocates custodianship via "provisions that give legal protection to the documentary collections of repressive organizations, as assets of cultural interest" (2009: 102): statutory provisions which involve both national and international courts. But he goes further in considering the records of the repression in more ambitious terms as the "heritage of an entire people... Taken as a whole and by extension, they are the heritage of all humanity to the extent that they can strengthen memory of the dangers of intolerance, racism and political totalitarianism" (González Quintana, 1998: 7-23).

The ambitious project of ensuring that this documentation becomes part of a legacy for humanity requires an integral archival and private-document management policy as part of a comprehensive public debate on the politics of memory. Some may ask, why the need to consider this documentation heritage? Or what benefits does this bestow to warrant implementing this integral archival management policy for the sake of memory? The answers to these questions lead us to four major considerations that shape the existence, conservation and dissemination of the archives of repression:

1. The consideration of the archives as "monuments of memory", which help prepare a collective memory, is crucial to carving out a common national identity. The benefits derived from this may help resolve issues related to shared national identification, associated with a traumatic past, such as those posed in present-day Spanish society. In this way, an underlying problem would be remedied and social memory would be built as a support base to sustain the structures of a more democratic future. All this would help achieve the overriding objective of accepting, as national heritage, the sacrifices of many in establishing the current values that sustain our democratic co-existence. In short, it is an objective that would contribute to the quality of democratic culture and the defense of human rights.

2 . For the victims, these documents are the key to recovering their personal memory (Da Silva Catela, 2002b: 213-214), which at the same time, contributes to the plural- 
ity of collective memories. As well as completing historical awareness about the past, the victim of the repression is benefited in terms of personal resignification. We thus create a two-way support channel between researcher and witness. This support takes the shape of offering them a chance to talk and tell their story, an action that can be seen as a form of psychological treatment to help overcome the trauma by giving the victim chance to express feelings and emotions openly. It also serves as redress, demonstrating to families that their dignity has not been lost.

3. All these documents contribute essential evidence of the highest significance in the legal context. Firstly, for victims they constitute the necessary proof to guarantee hypothetical reparations, including compensation, pensions or the return of confiscated goods ${ }^{19}$. I would once again point to the paradox that all these documentary repositories drawn up by the repressive forces currently exercise the opposite role from the perspective of victim support. The documents in question accuse those directly responsible for the repression, and also those who devised and ordered it.

In the case of Spain, however, a shocking peculiarity must be kept in mind. Although these documentary assets hold evidence against the perpetrators, owing to fear with which this traumatic past is approached, what these archives of repression really contain is evidence of impunity: impunity understood not only with regard to a very remote and, often, impossible adoption of legal action, but above all impunity with regard to the absence of recognition for the shameful actions carried out and the liabilities of their perpetrators. The shame is all the greater, if such is possible, when all these liabilities are understood as "patriotic duty, leading us to a peculiarly Spanish model of impunity" (Vinyes, 2010: 63).

4. Finally, all these documents are an essential foundation for historical research and, through it, for reconstructing the history of a society, discovering the truth of what happened during the darkest night of the contemporary age in Spain. Linked to this historiographical and academic production, one of the most important elements in the defense of the conservation and survival of this wealth of documents is their role as a trigger for educational action, aimed at raising awareness on the defense of human rights and fighting the intolerance that results from all forms of violation of these rights.

A society's traumatic remembrance of its dictatorial past remains one of the deepest possible wounds, one that continues to throb in the absence of clear public policies to manage this memory. The fracture is more intense when, as is the case in Spain, that traumatic past has been marked by civil war, and even greater where this war lasted three years and involved a violence that affected a large part of civil society (Gelonch Solé, 2013: 48).

After the conflict, winners and losers were condemned to live together. For the defeated, this co-existence is marked by a very clear memory policy towards the recent past, based on imposition of the victors' culture of war (Hernández Burgos and Del Arco Blanco, 2011: 74-78; Sevillano Calero, 2004: 142). The new regime was to build on the legitimacy of its victory in the war, a fact that was demonstrated in every village, where the defeated side was constantly subjected to acts of humiliation. The main reference framework for this humiliation was the public arena. The streets and squares of every village in Spain were to become a stage on which to showcase the values of the new regime. To this were added the military parades and political or religious ceremonies intended to demonstrate the strength of the State. The hegemony was also displayed through the symbolism and proliferation of crosses, religious images, flags, emblems with the Falange yoke and arrows and, above all, the placing of plaques honoring the fallen in central locations in each town or village, some of which still remain today. In the face of this, the defeated were subjected to a double degradation, forced to accept that any other symbol or ideology was "anti-Spanish".

For the children, widows and other relatives of the defeated, all that remained was humiliation and rejection by the rest of the community. They were forced to repress their sorrow and swallow their tears. Not only were they denied the right to express their pain and to mourn their dead, but they were deprived of the very moral and human right to cry (Ruiz-Vargas, 2006).

The specificities of the Spanish example help explain how difficult it is to establish a common collective memory, given that the memory of the defeated, which has never had a public space, cannot simply be deleted from the historical narrative and be kept concealed, as has occurred to date.

In his article, "Cuatro maneras de recordar un pasado conflictivo" [Four ways to remember a conflicting past], Stathis N. Kalyvas ${ }^{20}$ reflects on the issue, defining four phases or ways in which societies remember their troubled past. He explains how, when looking back to the past, societies may go through four different types of "collective memory": exclusion, silence, inclusion and conflict. Below I shall try to analyze the situation in Spanish society in line with the framework defined by Kalyvas.

The first of these regimes - that of exclusion - is based on the "culture of victory" explained above. In Spain, this moment occurred when there was only one official history of the civil war, written by the victorious side, offering a totally partisan view in which the defeated were constantly humiliated. The second regime - that of silence - describes those cases when contenders or their successors agree to forget. In Spain, this is the process that occurred during the transition to democracy where a sort of agreement was reached between the political elites to settle the issue by means of a consensual "amnesia" about the period. The next regime - inclusion - is linked to this, and is defined as the process by means of which an artificial consensus is reached, based on selective reconstruction of the past, where events are molded according to specific interests so that they fit into a desired vision which aims at a contrived inclusion of everyone. In Spain, this regime also reached its apex during the Transition with the construction of the collective myth "We were all to blame". 
These last two regimes are extremely vulnerable. A moment arrives when historians and other pro-memory stakeholders challenge the established memory and a regime of conflict emerges, where memories are divided and at loggerheads. At this point, private memories come out into the open, personal recollection emerges that contradicts the official memory, silenced acts of violence come to light and the fear of talking about the past finally disappears. The result is the breakdown of the official version.

This would appear to be the current situation in Spain. It seems to have been demonstrated that, as a memory policy, forgetting and silencing in no way contribute to overcoming past traumas. In the same way, the documentary examples used in the article and the different connotations associated with each of these make clear the importance of public policies to manage adequately these diverse document corpora, taking the necessary precautions to explain how each kind of documentation was created. The reconciliation of society as a whole with a traumatic past necessarily entails a supporting institutional framework that incorporates different memories of the past and dignifies the memory of the victims.

\section{NOTES}

1. Any exploration of the typology of the archives of the repression must include reference to the contributions made by Jelin and Da Silva Catela (2002) and González Quintana (2009).

2. To illustrate this paradox, the criteria followed in two specific cases should be considered: firstly, the military justice archives which were handed over to the Ministry of Defense, military justice being the most widely used format in the post-war period; and secondly prison records, in which case, even though all the information ought to be held by provincial historical archives, most are still administered by the Directorate General of Penal Institutions which reports to the Ministry of the Interior.

3. Examples of archives that hold this documentation are Archivo Histórico de Defensa, Archivo General Militar de Ávila or the Archivo General Militar de Guadalajara. See López Jiménez (2002 y 2005).

4. See result of Prime Minister's Office, Informe sobre archivos, 2006.

5 More information in Gaite Pastor (1994) and González Quintana (1994).

6. Extensive analysis in Herrerín López (2007).

7. See the systematic study of this archive in García Paz (2006).

8. See the systematic study of this archive in Ramos (2007).

9. Other prominent foundations which have engaged in the same task for different parties and unions include Fundación Largo Caballero (UGT) and Fundación Indalecio Prieto (Socialist organizations). For Anarchist organizations, Fundación Anselmo Lorenzo (CNT) and Fundación Salvador Segui (CGT). See Herrerín López (2007).

10. If we review briefly the countries where this kind of archive is found in terms of provenance, the archives created in Latin America necessarily stand out. One of the most important archival repositories of the Spanish Republican Government in Exile is in Mexico and contains documents produced by the Ateneo Español de México. In Argentina is the archival repository of Centro Republicano Español de Buenos Aires (CRE). The European country with most documentation on the subject is France. The Federación Española de Deportados e Internados Políticos (FEDIP) was based in Paris, and has a diverse archival repository comprising files on deported persons, acts of federation, correspondence, lists of diseappeared persons, etc. See Dávila et al. (2007) and Prime Minister's Office, Informe sobre archivos, 2006.
11. The tradition of this kind of archive is particularly important in Latin America. In some of its countries, civil society has reacted forcefully to the documentation derived from past dictatorships. Their compilation reflects the important role civil society has played in the defense and conservation of documents that provide evidence of human rights violations by the military dictatorships. I cite, by way of example, projects like Brasil: Nunca Mais (Da Silva Catela, 2002a: 15-84), Clamor also in Brazil (Lima, 2002:115-136), the Archive of the Vicaría de la Solidaridad in Chile (Cruz, 2002: 137-178) or Memoria Abierta in Buenos Aires (http://www.memoriaabierta.org.ar/ [accessed 12/ September/2014]); all clearly reflect the importance of civil society in defending and preserving documents demonstrating human rights violations during the military dictatorships in the Southern Cone.

12. Conxita Mir coined the term "efectos no contables de la represión" or "non-accounting entries of the repression" to refer to all those consequences of repressive practices that could not be measured in quantitative terms in the same way one can measure the numbers executed or imprisoned. She refers to all the repressive practices that seek to cause victims fear and terror, aimed at morally destroying them (Mir Curcó, 1999: 137139 and 144).

13. Archivo Histórico de Defensa, Madrid [AHD], Justicia Militar, Legajo 2934, Sumario 2323.

14. Research projects that try to make good this gap in our historical knowledge are of particular interest, such as those led by Antonio Castillo Gómez: Cultura escrita y memoria popular: tipologías, funciones y politicas de conservación (siglos XVI a XX) (HAR2011-25944) and Cinco siglos de cartas. Escritura privada y comunicación epistolar en España en la Edad Moderna y Contemporánea (HAR2008-00874/HIST).

15. Ferrándiz (2009a; 2009b) and Fernández de Mata (2009) have considered the process of mourning.

16. Interview with Enriqueta Mayoral Barea in Almadén on May $31^{\text {st }}, 2013$.

17. Spanish legislation on heritage and the latest act passed on the historical memory lack clear references promoting an integral archival policy on the management of the documents of the repression. Act 52/2007 of 26 December, which acknowledges and broadens rights, and establishes measures, for those who suffered persecution or violence during the civil war and the period of dictatorship, known as the Historical Memory Law, of which Article 21 undertakes to bring about the 'acquisition and protection' of any document 'referring to the Civil War or to the consequent political repression' both of 'public and private archives' to which it adds, in an explicit reference to the Spanish Historical Heritage Law (Act 16/1985), its protection as Documentary and Bibliographical Heritage. Although this represents a minimal step forward, though clearly insufficient, this law has, in any case, so far not been implemented.

18. Project 92.1 of the Spanish Prime Minister's Office "Todos los nombres de la represión de posguerra en Ciudad Real: investigación y material didáctico" " "All the names of the postwar repression in Ciudad Real: research and teaching material"] Department of Social and Cultural Anthropology, UNED. Directed by María García Alonso and Julián López García.

19. In present-day Spain, this would appear to be a very distant and even utopian aim. However, at particular moments, these documents have been used by victims to request a series of reparations, as indicated by Sierra Blas (2009: 1-17).

20. El País, November 22, 2006. http://elpais.com/diario/2006/11/22/ opinion/1164150013_850215.html [accessed 12/September/2014].

21. Translated from Spanish:

Soul of a Clown

What happens in the School of the Workers' Children

Behind the shutter / was the blind man's one / she was mad with fury / listening to the song / exclaimed by what had been rubbed out / calling for the justice / she wants done / with this headmaster / But all the pious prudes / who are part of his herd / defend 
the tyrant / and even cry for him / and the village thinks it very unfair [folded]/ and let them all go off / together to the same train / Laugh children / and carry on with your task and ask Mr. César / my new headmaster/ Ask him children / not to sell scholarships / or to sell your books / to those of his choosing. II

The one who defends him most is Esperanza / who used to be his / She'll always remember / those good times /that (...) he [folded] / and frightened the girls / because they were going to get into formation / and the other schoolmistresses / telling his friend / as they think the same way / they support him / there's a mystery in this / they are sad to lose him / they are the pets /of their good Headmaster / Laugh children / and carry on with your task and ask Mr. César / Ask him children /... not to sell scholarships /or to sell your books / to those of his choosing.

\section{REFERENCES}

Casanova, Julián (2003) La historia social y los historiadores: ¿cenicienta o princesa? Crítica, Barcelona.

Casanova, Julián (2009) "La historia social de los vencidos". Cuadernos de Historia Contemporánea, 30: 155-163. http://revistas.ucm. es/index.php/CHCO/article/view/CHCO0808110155A/6730. [accessed 12/September/2014]

Castillo Gómez, Antonio and Montero García, Feliciano (editors), (2003) Franquismo y memoria popular: escrituras, voces y representaciones. Siete Mares, Madrid.

Corominas Noguera, Mariona (2008) "Los archivos en el régimen franquista: la memoria histórica de una etapa política”. Entelequia: revista interdisciplinar, 7: 281-299. http://www.eumed. net/entelequia/pdf/2008/e07a17.pdf. [accessed 12/September/ 2014]

Cruz, María Angélica (2002) "Silencios, Contingencias y Desafíos: el Archivo de la Vicaría de la Solidaridad en Chile". In Los archivos de la represión: documentos, memoria y verdad, edited by Jelin, E. and Da Silva Catela, L. Siglo XXI, Madrid: 137-178.

Da Silva Catela, Ludmila (2002a) "Territorios de memoria política. Los archivos de la represión en Brasil". In Los archivos de la represión: documentos, memoria y verdad, edited by Jelin, E. and Da Silva Catela, L. Siglo XXI, Madrid: 15-84.

Da Silva Catela, Ludmila (2002b) "El mundo de los archivos". In Los archivos de la represión: documentos, memoria y verdad, edited by Jelin, E. and Da Silva Catela, L. Siglo XXI, Madrid: 195-221.

Da Silva Catela, Ludmila and Jelin, Elizabeth (editors), (2002) Los archivos de la represión: documentos, memoria y verdad. Siglo XXI, Madrid.

Dávila, Alfonso, Lijarcio Villa, Juan José y Sierra, Carmen (2007) "El exilio en los archivos de titularidad del Ministerio de Cultura". Migraciones \& Exilios: Cuadernos de la Asociación para el estudio de los exilios y migraciones ibéricos contemporáneos, 8: 11-31. http://dialnet.unirioja.es/servlet/articulo? codigo $=2547719$. [accessed 12/September/2014]

Didi-Huberman, Georges (2008) Images in Spite of All: four Photographs from Auschwitz. University of Chicago Press, Chicago.

Fernández de Mata, Ignacio (2009) "In memoriam... esquelas, 'contra-esquelas' y duelos inconclusos de la Guerra Civil Española". Historia, antropología y fuentes orales, 42: 93-127.

Ferrándiz Martín, Francisco (2009) "Exhumaciones y relatos de la derrota en la España actual". Revista de Historia Jerónimo Zurita, 84: 135-162. http://digital.csic.es/bitstream/10261/24505/1/ Jeronimo Zurita 2009.pdf. [accessed 12/September/2014]

Ferrándiz Martín, Francisco (2009) "Fosas comunes, paisajes del terror". Revista de Dialectología y Tradiciones populares, 64.1: 6194. http://rdtp.revistas.csic.es/index.php/rdtp/article/view/70/71. [accessed 12/September/2014]

Gaite Pastor, Jesús (1994) "Fondos de Guerra Civil y Posguerra en la Sección Fondos Contemporáneos del Archivo Histórico Nacional". Espacio Tiempo y Forma. Serie V, Historia Contemporánea 7: 455-478. http://e-spacio.uned.es/revistasuned/index.php/ETFV/ article/view/2999/2859. [accessed 12/September/2014]
García Paz, Beatriz (2006) "Fundación Pablo Iglesias: Documentación sobre la represión franquista". Hispania Nova. Revista de Historia Contemporánea, 6. http://hispanianova.rediris.es/6/ dossier/6d011.pdf. [accessed 12/September/2014]

González Quintana, Antonio (1994) "'Fuentes para el estudio de la represión franquista en el Archivo Histórico Nacional, Sección Guerra Civil". Espacio Tiempo y Forma. Serie V, Historia Contemporánea, 7: 479-508. http://e-spacio.uned.es/fez/eserv. php?pid=bibliuned:ETFSerie5-03AABFF0-AB32-42A1-58D359215AF5155C\&dsID=Documento.pdf. [accessed 12/September/ 2014]

González Quintana, Antonio (1998) "Archives of the security services of former repressive regimes". Janus, 2: 7-25.

González Quintana, Antonio (2009) "Políticas archivísticas para la defensa de los Derechos Humanos". Actualización y ampliación del informe elaborado para UNESCO y Consejo Internacional de Archivos (1995) sobre gestión de los archivos de los servicios de Seguridad del Estado de los desaparecidos regímenes represivos. Fundación 10 de Marzo, Santiago de Compostela. www.ica.org/download.php?id=972. [accessed 12/ September/2014]

Halbwachs, Maurice (2004) Los marcos sociales de la memoria. Anthropos, Barcelona.

Hernández Burgos, Claudio and Del Arco Blanco, Miguel Ángel (2011) "Más allá de las tapias de los cementerios: la represión cultural y socioeconómica en la España franquista (1936-1951)". Cuadernos de Historia Contemporánea, 33: 71-93. http://revistas.ucm.es/index.php/CHCO/article/view/36666/35505. [accessed 12/September/2014]

Herrerín López, Ángel (2007) "Los archivos de organizaciones políticas y sindicales y el exilio". Migraciones \& Exilios: Cuadernos de la Asociación para el estudio de los exilios y migraciones ibéricos contemporáneos, 8: 33-52. http://dialnet. unirioja.es/servlet/articulo?codigo $=2547731$. [accessed $12 / \mathrm{Sep}-$ tember/2014]

Lacerda, Silvestre (2010) "Los archivos de la PIDE y la represión en el Portugal Salazarista”. In Represión, derechos humanos, memoria y archivos: una perspectiva latinoamericana, edited by Babiano Mora, José. Fundación $1^{\circ}$ de Mayo, Madrid: 127-140.

León Portilla, Miguel (1984) Visión de los vencidos: Relaciones indígenas de la conquista. Universidad Nacional Autónoma de México, México. ( $1^{\circ}$ ed. 1959$)$

Lima, Samarone (2002) "Clamor: la colcha de retazos de la memoria". In Los archivos de la represión: documentos, memoria y verdad, edited by Jelin, E. y Da Silva Catela, L. Siglo XXI, Madrid: $115-136$.

López García, Julián (2014) "Pequeñas cosas de un tiempo de espinas". In Homenaje a Francisco Caudet (in press).

López García, Julián and Pizarro Ruiz, Luis F. (2011) Cien años para la libertad: historia y memoria del socialismo en Puertollano (1910-2010). Agrupación Local del Partido Socialista Obrero Español, Puertollano.

López Jiménez, F. Javier (2002) "Historia militar: métodos y recursos de investigación". Revista de Historia Militar, año XLV, 1.

López Jiménez, F. Javier (2005) "Las fuentes: los archivos militares". Ayer, 57: 27-49.

Mir Curcó, Conxita (1999) "Violencia política, coacción legal y oposición interior". Ayer, 33: 115-146.

Mir Curcó, Conxita and Gelonch Solé, Josep (editors), (2013) Duelo y memoria. Espacios para el recuerdo de las víctimas de la represión franquista en la perspectiva comparada. Universitat de Lleida, Lleida.

Nora, Pierre (1984) « Entre mémoire et histoire. La problematique des lieux ». In Les lieux de mémoire, 1, La Republique, edited by Nora, Pierre. Gallimard, Paris: 23-43.

Plummer, Kenneth (1983) Documents of life: an introduction to the problems and literature of a humanistic method. George Allen \& Unwin, London.

Pollack, Michael (2006) Memoria, olvido, silencio. La producción social de identidades frente a situaciones límite. Ediciones la Margen, La Plata. 
Ramos, Victoria (2007) "La represión franquista en el archivo histórico del PCE". Hispania Nova, Revista de Historia Contemporánea, 7 . http://hispanianova.rediris.es/7/dossier/07d005. pdf. [accessed 12/September/2014]

Ricoeur, Paul (2004) Memory, history, forgetting. University of Chicago Press, Chicago.

Ruiz-Vargas, José María (2006) "Trauma y memoria de la Guerra Civil y de la dictadura franquista". Hispania Nova. Revista de Historia Contemporánea, 6. http://hispanianova.rediris.es/6/ dossier/6d012.pdf. [accessed 12/September/2014]

Sevillano Calero, Francisco (2004) Exterminio. El terror con Franco. Oberon, Madrid.
Sierra Blas, Verónica (2009) "La indemnización del terror. Reconocimiento social y documentos personales". IV Jornadas Archivo y Memoria. La memoria de los conflictos: legados documentales para la Historia. Fundación de Ferrocarriles españoles y CSIC, Madrid: 1-17.

Vinyes, Ricard (2010) "Las políticas públicas de reparación y de la memoria en España". In Represión, derechos humanos, memoria y archivos: una perspectiva latinoamericana, edited by Babiano Mora, José. Fundación $1^{\circ}$ de Mayo, Madrid: 57-68. 